\title{
DIE VERPLEEGSTER EN DIE OMGEWING
}

\author{
G. Oberholster, M.B. Ch.B., D.V.G., D.B.G., D.G.A.
}

Adjunk-Direkteur, Afdeling Omgewingsgesondheidsdienste, Departement van Gesondheid

\section{SUMMARY}

As health services, including nursing, are often directed more to the personal aspects, it is easy to forget that the nurse also plays an important role in environmental health services. Some of these aspects are discussed and it is emphasized that she is a member of the health team with an important role in health education.

\section{INLEIDING}

1979 is Gesondheidsjaar en uitdrukkings soos "Gemeenskapsbetrokkenheid, ter wille van 'n gesonder gemeenskap en primêre gesondheidsorg" kom algemeen voor in die gesproke en geskrewe woord.

Terwyl nadruk veral gelê word op die betrokkenheid van die gemeenskap by die pasiënt se gesondheidsorg, asook die voorkoming van siektes deur die beskikbaarstelling van gespesialiseerde dienste, is dit maklik om te vergeet dat die gemeenskap, vanaf die jongste tot die oudste, die sieke en die gesonde, die kleuter, die skolier, die huisvrou, die werker, en die afgetredene, almal binne 'n omgewing leef, werk en ontspan en dat die kwaliteit van daardie omgewing 'n uitwerking op die persoon se gesondheid moet hê.

Tradisioneel is omgewingsgesondheid die werksfeer van die gesondheidsinspekteur en die vraag ontstaan nou watter rol het die verpleegster hierin te speel? Die antwoord hierop is tweeledig naamlik:

(i) die verpleegster is ' $n$ lid van die gesondheidspan en, hoewel hul take onderling mag verskil, moet sy met haar kollegas in verskillende dissiplines saamtrek in die span. Dit is dan ook haar plig om binne die spanverband die probleme wat sy teëkom na haar spesifiek gekwalifiseerde spanmaat te verwys vir optrede; en

(ii) weens die vertrouensposisie van die verpleegster en haar nou kontak met die gemeenskap, is die verpleegster uitmuntend geskik vir gesondheidsvoorligting, wat dan ook omgewingsgesondheidsvoorligting insluit. Hierdie is 'n plig wat sy onder geen omstandighede mag verwaarloos nie.

\section{WAT IS OMGEWINGSGESONDHEID?}

Die verdere vraag ontstaan nou onwillekeurig naamlik wat is omgewingsgesondheid of wat behels hierdie taak waarin die verpleegster so goedsmoeds betrek word? Hierop is daar feitlik geen afdoende antwoord nie, want die omvang van omgewingsgesondheid is feitlik net so wyd as wat 'n mens daaraan wil dink.
Baie breedvoerig kan daar geredeneer word dat dit alles omvat waaraan 'n persoon blootgestel word en kan dit opgedeel word in fisiese, chemiese en biologiese komponente. Selfs binne hierdie komponente mag daar oorvleueling wees en daar mag aspekte wees wat moeilik onder enige indeelbaar is, bv. by die verskaffing van 'n gerieflike huis, kan daar maklik oor die termiese gedrag van die dak, mure en vloer geredeneer word, of selfs oor die chemiese kwaliteit van die water en die higiëniese beskikking oor afval met 'n moderne rioolstelsel, maar waar word daardie gevoel van tuis te wees en die verbetering in die sosiale en morele welsyn by die inwoners, wat deur 'n verbetering in 'n omgewingstoestand teweeggebring is, ingedeel?

\section{DIE ROL WAT DIE VERPLEEGSTER KAN SPEEL IN OMGEWINGSGESONDHEID \\ Behuising}

Die mens benodig skuiling van die elemente. Deur die eeue het hy 'n meer gesofistikeerde smaak vir skuiling ontwikkel en het meer elegante en doeltreffende skuilings vir hom gebou. Kennis aangaande minimum gesondheidstandaarde vir behuising het egter ook ontwikkel sodat daar vandag met sekerheid reels in hierdie verband neergelê kan word. Ongelukkig is 'n groot gedeelte van ons gemeenskap nie daartoe in staat om uit eie vermoë die minimum standaarde te handhaaf nie en moet hul eenvoudig regkom met wat hul tot hul beskikking het. Dit lei tot die onstaan van krotbuurtes met die swakste omstandighede denkbaar. Daar is gewoonlik geen watervoorsiening en huishoudelike en nagvuilbeskikking nie. Hierdie krotbuurtes ontstaan gewoonlik in die omgewing van stede en dorpe, maar kan ook soms gesien word as deel van geordende woonbuurtes by kleiner dorpies asook op plase waar die eienaar of nie behuising aan sy werkers voorsien nie, of onbeheerde plakkery op sy eiendom toelaat.

Die verpleegster se rol is hier onbenydenswaardig maar duidelik. Eerstens behoort sy haar invloed by die verantwoordelike persone of owerhede te gebruik om hierdie tipe toestand te voorkom of te orden sodat dit 
met die minste moontlike gesondheidsgevaar voortbestaan, totdat alternatiewe reelings getref kan word. Tweedens is haar rol dié van 'n gesondheidsvoorligter om die inwoners te leer om onder die omstandighede op die mees higiëniese wyse te leef veral wat betref die hantering van water en voedsel en die beskikking oor huishoudelike afval en nagvuil. Elke verpleegster behoort dus die beginsels te ken van ten minste die konstruksie van 'n vliegdigte putlatrine en die higiëniese beskikking van huishoudelike afval in die grond.

\section{Algemene Omgewingshigiëne}

Die handhawing van higiëne in en om die huis is van die grootste belang. Benewens die aspekte reeds aangeraak, word hier veral gedink aan die higiëniese berging, voorbereiding en hantering van voedsel. Knaagdiere en insekte kan voedsel besmet indien dit nie doeltreffend geberg word nie. Voedsel kan deur die hanteerder of werkoppervlaktes besmet word indien daar nie toegesien word dat die hanteerder nie aan sekere oordraagbare siektes ly en werksoppervlaktes glad en skoon is nie. Voedsel wat reeds voorberei is, is ' $n$ goeie teëlaarde vir mikro-organismes wat tot verskillende ingewandsinfeksies kan lei.

'n Aspek wat ook nie uit die oog verloor moet word nie, is die aanhou van en hul kontak met mense. Die eet van maselbesemette varkvleis en die aanhou van varke wat op die werf loop waar hul tot menslike ekskreta toegang het, kan lei tot verdere lintwurminfestasies. Onder soortgelyke omstandighede, kan rondewurminfestasies by kinders ook voorkom en besmette troeteldiere kan ander parasiete tot die mens oordra.

Weer eens kan die verpleegster in haar voorligting en opvoedingstaak van onskatbare waarde wees.

\section{Water- en Oppervlaktebesoedeling}

Die Republiek is ' $n$ land wat oor die algemeen arm is aan water. Met die uitsondering van sekere kusgebiede met 'n hoë reënval en baie water, is die grootste deel van ons land afhanklik van 'n beperkte aantal riviere en damme. Dit is dus van die allergrootste belang dat die beskikbare water so ekonomies moontlik aangewend word en dat dit weer tot verdere gebruikers beskikbaar gestel moet word. Die Staat is dan ook tans besig met 'n aantal skemas waar water uit natter dele aan droër dele beskikbaar gestel word bv. die Tugela-Vaalskema, die Oranje-Visskema en die RiviersonderendBergrivierskema.

Besoedeling van die oppervlakte lei weer tot waterbesoedeling. Benewens sekere punte reeds behandel, vind waterbesoedeling plaas deur die ongemagtigde storting van vaste- of vloeibare afval op die oppervlakte of in ons watervoorrade. Storting kan soms weens onkunde wees, maar soms ook doelbewus om bv. stortingsfooie by 'n stortingsterrein te vermy. Hoe goed ken ons nie die prentjie van motorwrakke, leë dromme, boupuin of ander gemors in ons spruite en riviertjies nie? Hoe lyk die oppervlakte en die omgewing van ons damme en riviere nie van blikkies, kartonne en plastiese sakke na 'n naweek se ontspanning langs ons waters nie?

Ook hier kan die verpleegster 'n rol speel, nie alleen by die aanmelding van oortredings nie, maar deur haar opvoeding en voorligting en die stel van 'n voorbeeld. Dan kan sy ook desnoods haar oorredingsvermoë gebruik om die verantwoordelike persone en owerhede sover te kry om die nodige wegdoeningsfasiliteite daar te stel.

\section{Gevaarlike Stowwe en Medisynes}

'n Groot aantal stowwe wat daagliks in ons lewens gebruik word, is gevaarlik indien hul op verkeerde plekke of in verkeerde hande beland. Bekende voorbeelde hiervan is plaagdoders wat in voedsel beland, paraffien wat in koeldrankbottels aangehou word en medisynes wat in kinderhandjies beland.

Daar bestaan voorskrifte hoe plaagdoders hanteer en geberg moet word en veral hoe leë houers beskik moet word, maar gevalle van vergiftiging word gereeld aangemeld. Net so gereeld word kinders tot hospitale toegelaat omdat hul brandstof of 'n oormaat medisynes ingekry het.

Verpleegsters behoort op hoogte te wees met die veilige hantering van plaagdoders, sowel as die voorskrifte ten opsigte van die wegdoen van houers. Dieselfde geld vir die ophoping van ongebruikte medisynes en die verkeerde aanwending daarvan. Medisynes behoort altyd agter slot en grendel buite die breik van kinders geberg te word.

'n Praktyk wat ook ontmoedig moet word, is die ooren-weer leen of gee van ogebruikte medisynes tussen kennisse en vriende. Om voorligting en kennis te versprei oor die voorgaande is 'n taak wat uitmuntend by die verpleegster pas, veral waar sy met siek mense te doen kry.

\section{Voedingsmiddels, Skoonheidsmiddels en Ontsmet- tingsmiddels}

Al die genoemde middels, waarmee die mens een of ander tyd in aanraking kom, is onderhewig aan beheer betreffende die inhoud en chemiese samestelling.

Wat voedingsmiddels betref, is daar slegs sekere kleurstowwe, versoeters, emulsifiseerders en preserveerders wat tot vasgestelde maksimum konsentrasies toegelaat word. Streng etiketteringsvereistes wat die beskrywing van die inhoud betref, word nok gestel. Sekere ander voedselsoorte bv. boerewors in roomys is ook onderhewig aan streng kwaliteitsvereistes.

Sommige chemikalieë bv. kwik is verbode as 'n bestanddeel van sekere skoonheidsmiddels, veral velbleikmiddels, omdat die gebruik daarvan aanleiding tot ander velkwale gee. Ondanks die verbod, word hierdie middels soms nog wederregtelik ingevoer en verkoop.

'n Aantal plaaslike besture is kragtens die paslike wetgewing gemagtig om monsters van voedingsmiddels te neem en te laat ontleed. In hierdie opsig kan die verpleegster die gesondheidinspekteur van hulp wees deur haar oe oor die etikette van voedingsmiddels en skoonheidsmiddels te laat gly wanneer sy die kleinhandelaar, afdelingswinkel of apteek besoek, en dan enige ongerymdhede rapporteer. Daarbenewens kan sy tegelykertyd oplet na sulke aspekte soos skoonheid en netheid van en die korrekte hantering van voedsel deur verkoopsassistente, asook die toestand van kleedkamers. 
Tegelykertyd kan sy met haar opvoedings- en voorligtingstaak voortgaan vir die personeel.

\section{Stralingbeheer}

Die gebruik van Röntgenstrale of X-strale is 'n uiters nuttige diagnostiese hulpmiddel waarsonder ons baie moeilik die moderne gesondheidsdiens kan indink. Ongelukkig hou die oormatige gebruik van $\mathrm{X}$-strale egter ook gevare in vir blootgesteldes, hetsy hul die operateurs, pasiënte of ander toevallig blootgesteldes is.

Uit die aard van haar werk, veral met die beheer van tuberkulose en die aanvraag van long-X-foto's, kan die verpleegster indirek bydra tot onnodige bestraling van pasiënte. Verdere punte waarop sy kan let is dat vroeë swangerskappe aangemeld word en sulke pasiënte nie onnodig bestraal word nie of dat onnodige of oorbodige voorgeboortelike X-foto's geneem word. Verder kan sy ook daarop let dat operateurs hul filmwapentjie dra en dat bystanders bv. ouers en familielede van pasiënte nie onnodig bestraal word of die nodige beskermende klere dra.

\section{Beheer van Lugbesoedeling}

Die beheer oor lugbesoedeling word tans in vier kategorieë opgedeel te wete beheer oor ingelyste prosesse, bekamping van stof vanaf mynhope, beheer oor die uitlate van dieselvoertuie en die beheer oor rook uit huishoudelike verhittingtoestelle.

Die beheer oor eersgenoemde twee kategorieë word deur die Departemente van Gesondheid en Mynwese onderneem, terwyl die beheer oor laasgenoemde twee kategorieë na die plaaslike besture gedelegeer is.

Dit sal nie van 'n verpleegster verwag word om dicselvoertuie se rookuitlate te toets nie en hierdie kalegorie is dus nie vir haar van primêre belang nie. Wat egter wel vir haar van belang is, is huishoudelike rookbeheer.

Deur bemiddeling van die Nasionale Advieskomitee op Lugbesoedeling word 'n nuwe tipe hout of steenkoolstoof tans bemark. Hierdie "minimum rook" stoof, waarvan daar etlike soorte op die mark is, het die konvensionele stoof vervang en is so ontwerp dat die hout of steenkool feitlik rookloos verbrand.

Die effektiewe werking van die stoof hang egter af van die gebruik van die regte grootte steenkool en die korrekte stookmetodes. Dit gebeur ook soms dat weens die foutiewe gebruik van die vuuryster, sekere dele van die stoof beskadig word met gevolglike rookproduksie.

Die rook wat soggens en saans oor sommige van ons woongebiede hang, is 'n welbekende dog onwelkome gesig en kan grootliks verminder word deur die gebruik van die "minimum rook" stoof. Die verpleegster kan 'n baie positiewe bydrae tot die beheer van lugbesoedeling lewer as sy die werking van hierdie stoof goed onder die knie kry en dit as ' $n$ deel van haar voorligtingstaak beskou om die eienaars in die regte metode van die hantering van die "minimum rook" stoof oplei.

\section{Vektorgedraagde Siektes}

Daar bestaan 'n aantal siektes waarin vektore 'n belangrike rol speel en wat gevolglik uit die omgewingsgesondheidoogpunt ook belangrik is. Enkele voorbeelde is malaria, pes, tifus en bilharzia. Hoewel in al hierdie gevalle die uitroeiing van die vektore en die bekamping van omstandighede wat die vektore bevoordeel, 'n belangrike rol speel, is dit van groter belang dat die blootgestelde publiek goed ingelig moet wees oor die voorkoms van die betrokke siektes en die maatreëls wat hul kan tref om die siektes te voorkom.

Terwyl dit dus van die verpleegster kan verwag word om in 'n spanverband saam te werk om bloedsmere of urinemonsters te neem gedurende 'n uitbraak van 'n opname oor sulke siektes, is dit weer waar haar opvoedings- en voorligtingstaak na vore kom.

Terselfdertyd kan sy ook tydens haar normale pligte, oplet vir of verneem na 'n verhoogde voorkoms van muskiete of 'n abnormale vrekte onder knaagdiere in die omgewing. Hierdie inligting kan die gesondheidspan in staat stel om betyds op te tree.

\section{Bedryfsgesondheid}

Die werker in die nywerheid is in die unieke posisie dat hy homself tydens sy werk feitlik in 'n mikroomgewing bevind. Hier is hy blootgestel aan fisiese faktore, soos uiterstes van temperatuur, lawaai en vibrasie, chemiese faktore soos stof, irriterende gasse en giftige chemikalieë of biologiese faktore soos katoenstof en soonoses. Daarby werk hy soms nog onder druk om 'n vooropgesette werksvolume te handhaaf of onder abnormale omstandighede bv. skofwerk.

Bedryfsgesondheidverpleging is die dissipline wat op die probleme van hierdie werker toegespits is. Hier vind die verpleegster haar ook dikwels in die gesondheidspan van die bedryfsgeneesheer, bedryfshigiënis en veiligheidsbeampte, dog net so dikwels vind sy haar heeltemal alleen, aangestel as 'n "eerstehulpsuster"' met slegs beperkte personeel om haar by te staan.

Hierdie dissipline kan as ' $n$ spesifieke spesialisasierigting binne die omgewingsgesondheid beskou word en dit word van haar verwag om 'n deeglike kennis van al die dissiplines wat binne hierdie verband werk, te beskik. Ook word dit van haar verwag om baie goed op hoogte van sake te wees met al die gesondheidsgevare wat binne die betrokke nywerheid of fabriek aangetref word. Nie alleen moet sy die werker kan voorlig en opvoeding in die voorkoming van gesondheidsgevare gee nie; maar sy moet kan toesien dat hy enige instruksies in hierdie verband nakom. Sy moet ook 'n diens aan hom lewer in die vorm van ondersoeke en monsterneming en indien nodig, spesifieke noodhulp.

Hierdie betrokke rigting binne die verpleegkunde gaan tans met rasse skrede vooruit binne die Republiek en bied werklik 'n uitdaging aan die verpleegster.

\section{Algemeen}

In die loop van haar werk, besoek die verpleegster 'n aantal uiteenlopende instansies. As lid van die gesondheidspan is dit haar plig om omstandighede om haar waar te neem en haar spanlede in te lig. Tydens 'n besoek aan 'n skool sal sy nie net na die gesondheid van die leerlinge omsien nie, maar sal sy oplet na die algemene netheid van die skoolgronde, die watervoorsiening, die aantal kleedkamers en toilette vir elke geslag en die toestand waarin hul is. By 'n besoek aan 'n voedselonderneming sal sy ook na die genoemde punte oplet sowel as die higiëne en netheid van die voedselhanteerders en die apparaat deur hulle gebruik. In alle gevalle sal sy die nodige verslag doen en sake verwys na haar betrokke kollegas in die span vir spesifieke opvolging. Verder sal sy ook voortgaan met haar taak van voorligting en opvoeding. 